
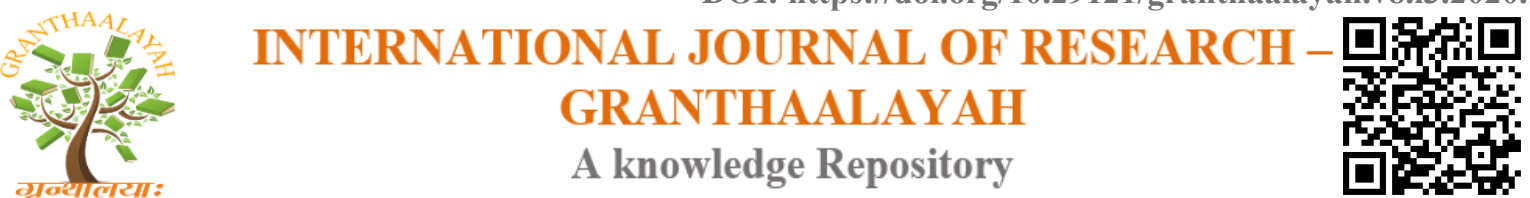

Science

\title{
BIOSTRATIGRAPHIC CORRELATION OF PALEOZOIC ROCKS IN NORTHERN AND WESTREN IRAQ
}

\author{
Falah H. Khalaf Al-jubori (B.Sc., Ph.D.) ${ }^{1}$, Akram K. Youkhana (B.Sc., Ph.D.) ${ }^{2}$, Srood F. \\ Naqshabandi (B.Sc., Ph.D.) ${ }^{3}$, Dyana A. Bayz (B.Sc., M.Sc.) ${ }^{1}$ \\ ${ }^{1}$ Knowledge university, College of Engineering, Department of petroleum Engineering. Erbil, \\ Kurdistan Region, Iraq \\ ${ }^{2}$ Ex- expert Geologist, Ministry of Oil, Oil Exploration Company, Iraq \\ ${ }^{3}$ Department of Geology, College of Science, Salahaddin University, Erbil, Iraq
}

\begin{abstract}
The Paleozoic rocks outcropped in northern Iraq (Ora, Chia Zairi section) are biostratigraphically investigated for their microfossils content. Benthonic foraminifera and algal genera characterize the upper part of the section while palynomorphs (Miospores \& Acritarchs) dominated the lower part the section which is consist of clastic sediments. The study also include the stratigraphic succession of the section and its correlation to the subsurface sections penetrated in oil and water wells drilled in the western desert of Iraq in order to determine the regional distribution of the economically important formations, either as reservoir or as source rocks for hydrocarbons. Index palynomorphs including many types of Acritarch genera are identified in the Khabour Formation indicate lower Ordovician time (Tremadocian? Arenigian -Llanvirnian: age) The Perispik Formation has been found barren of any type of microfossils and is composed of red clastic rocks. Pollen and Spores are recorded from the "Ore Group" (Kaista, Ora and Harur Formations ) indicate that these rocks are of Upper Devonian - Lower Carboniferous (Famennian - Tournaisian age ).A Large number of foraminifera and Algal genera are identified in the Chiazairi rocks, these genera and species are indicated the Upper Permian rocks of Thuringian age.

The stratigraphic succession of the Paleozoic section studied in northern Iraq indicate that there is a stratigraphic break represents by missing of the Ga'ara Formation (late Carboniferous -early Permian) and Akkas Formation (Silurian) and the upper part of the Khabour Formation (Upper Ordovician).
\end{abstract}

Keywords Acritarchs; Algae; Biostratigraphy; Foraminifera; Miospores; Palynology.

Cite This Article: Falah H. Khalaf Al-jubori, Akram K. Youkhana, Srood F. Naqshabandi, and Dyana A. Bayz. (2020). "BIOSTRATIGRAPHIC CORRELATION OF PALEOZOIC ROCKS IN NORTHERN AND WESTREN IRAQ." International Journal of Research - Granthaalayah, 8(3), 315-323. https://doi.org/10.29121/granthaalayah.v8.i3.2020.163. 


\section{Introduction}

Paleozoic rocks in Iraq are exposed in a very limited area in northern Iraq forming a narrow stripe along the Iraq - Turkish border (Wetzel, 1950). It also occurs at the western desert of Iraq (Rutbah High) where exposure of a clastic rocks (Ga'ara Formation ) occurs in the base of Ga'ara depression (Buday, 1980).

The Paleozoic rocks exposed in northern Iraq reach thickness of about 2000 meters (Wetzel R.1950). consisting of carbonate rocks (Chia Zairi Formation) upper Permian, Ora Group (Perispiki, Kaista, Ora and Harur Formations) of upper Devonian - Lower Carboniferous time and Khabour Quartzite and shale beds of Ordovician time (Bellen et al 1959).

The Paleozoic rocks are also partly or completely penetrated in many exploration wells drilled in northern Iraq (Jabel kand -1, Atshan -1 and Mityaha -1) where the drilling reach the Chia Zairi Formation (Upper Permian )while in the exploration well Jabel kand -1, the Harur Formation of Lower Carboniferous age is reached.

Oil and water wells drilled in the western part of Iraq e.g. Khlessia well-1, drilled on Khlessia high penetrated the Paleozoic rocks to the lower part of the Khabour Formation (Ordovician) (Gaddo and parker,1959).

Oil and water wells drilled in western desert of Iraq penetrate the Paleozoic section e.g. Akkas 1, reach the lower part of the Khabour Formation (F. Khalaf et. al .1998). Water Wells KH5/1, and KH5/6 reach Akkas Formation (Silurian), Berikdar and Al-jubori 1985, (Internal Reports), AlAmeri et al .1991.

Other exploration wells drilling in southern Iraq e.g. well West Kifl -1, penetrated Chia Zairi Formation and the upper part of the Ga'ara Formation (F.Khalaf et al,1986,1988), Well Diwan 1, reach Chia Zairi Formation ( Upper Permian ) Khalaf et al (1989),internal report.



Figure 1: Location Map 


\section{Aim of the Study}

The study is mainly emphasized on the occurrence and identification of microfossils (Foraminifera Algae and Palynomorphs Spores \&Pollen \& Acritarchs) present in the Paleozoic rocks that have been mapped by Wetzel, 1950. which is outcropped in Northern Iraq .The study aimed to reevaluate the geologic age of the formations representing the Paleozoic rocks in the exposed area in order to correlate with subsurface Paleozoic rocks penetrated in the exploration wells drilled in other part of Iraq the study was proposed by a group who restudied and re- evaluate the Paleozoic section which is penetrated in well Khleissia -1, in order to determine the geographic distribution of the Silurian rock (Akkas Formation) towards the outcrop area at north Iraq as these rocks (Silurian rocks ) are proved to be a good source for hydrocarbon generation in the Paleozoic rocks.

\section{Geographic Location and Sampling}

The area studied is located in extreme north Iraq on northern limb of Ora mountain (figure -1 ), the exposed Paleozoic section was mapped and studied by (R. Wetzel,1950), consist of the Chia Zairi Formation (Permian ), Ora group (upper Devonian- lower Carboniferous) and the Khabour Formation (Ordovician ). The whole section reach thickness of about (1515) meter.

Sixty five (65) samples were selected for the palynological analysis. These samples were collected and numbered by (R. Wetzel 1950) and stored in the core and cutting stores in the Laboratory department, Oil Exploration Company, Baghdad, Iraq. The rock samples were re-analyzed chemically and physically by the standard methods applied for palynological analysis in the calcareous and siliceous sediments by using hydrochloric and hydrofluoric acids $(\mathrm{HCl}, \mathrm{HF})$ starting with $\mathrm{HCl}$ then $\mathrm{HF}$, latter separating the organic matter which include also the palynomorphs and then preparing palynological slides for the purpose of identification and recording the different types of the palynomorphs present in each analyzed sample in order to interpret the geologic age. In this study, also the samples and rock thin sections collects and prepared by Wetzel,1950, were re-used to study the microfacies and identification of Foraminifera and Algal genera present in the Paleozoic rock sections.

\section{Stratigraphic Succession of The Exposed Paleozoic Rocks in Northern Iraq}

The oldest known rocks in Iraq are exposed in the extreme northern Iraq, these rocks are also penetrated in some exploration oil wells drilled in north, west and southern Iraq.

In Iraq the oldest known formation is Khabour Quartzite, consist mainly of shale and sandstone might overly Cambrian sediments with some calcareous thin beds (Burj limestone) based on correlation with neighboring countries Buday et.al (1980). This is also known from the geophysical correlations with Syria, Jordan and western part of Iraq. The deep wells in Syria and Jordan have penetrated the clastics and carbonate rocks that are represented by Saq and Burj Formations (middle-Cambrian). These rocks might be also present, at least, in the western part of Iraq underlying the Khabour Formation. 
The exposed Paleozoic rocks at northern and western part of Iraq have been studied by Boech (1938), Wetzel (1950), Wetzel and Morton (1952) Bellen et .al. (1959), as a result of these studies, three sedimentary cycles were proposed for the deposition of Paleozoic rocks, as follows:
Permian
Chia Zairi limestone with evaporate
Lower Carboniferous
Harur limestone, Ora shale,
Upper Devonian
Kaista Formation
Upper Ordovician
Pirispiki red beds with Chalki volcanic
Lower Ordovician
Khabour quartzite shale

Buday (1980), also propose three sedimentary cycles for the Paleozoic rocks as follows

1) The Cambro - Ordovician to (? Silurian) cycle represented by the Khabour Quartzite and shale Formation.

2) The Upper Devonian. Lower Carboniferous cycle which consists of Perispiki red beds, Chalky volcanic, the Krista Ora shale and Harur limestone Formation.

3) The Upper Carboniferous to (?) Upper Permian cycle represented by the Ga'ara sandstone and Chia Zairi (carbonate \& evaporates) Formation.

\section{Biostratigraphy}

For the purpose of palynological study, sixty-five (65) samples have been analyzed and palynological thin section were prepared by the way previously discussed. To identify and record the microfossils content (foraminifera and Algae). The thin sections prepared and studied by Wetzel R. (1950) were used also in this study. Extra samples have prepared from the subsurface sections were also used and their micro faunal content were recorded.

Palynological study of the exposed section show presence of pollen and spores with Acritarchs in the rocks forming the lower part of the sediment which consists of clastic rocks while foraminifera and algae are the main microfossils recorded in the upper part of the exposed sediment which consists of carbonate rocks (Chia Zairi Formation).

The Biostratigraphy of the Paleozoic section is discussed below, as the section is exposed on the surface, sample study starts from the lower part of the section as the samples numbered by Wetzel R. (1950).

\subsection{Khabour Formation: (thickness 246 meters)?}

The section is limited between sample (700 IWL- 7048 WL), It consist of thin beds of fine sand, silt and shale with quartzite, the section was found barren from any type of foraminifera and Algae while it yields many genera of Achritarchs.

The identified genera and species of Achritarch are listed below, they characterize the globally Ordovician sediments and indicate Lower Ordovician (Tremadocian, Arenigian- Lianvirnian age) There are:

Actinodissus sp.

Vulcanisphaera? cf. afrricana

Veryhachium cf. splendens 
Striatotheca principalis

Priscothera cf. diadela

Peteinoshaeridium cf. dissimillis

Polygonium spinosum

Camasphaeridium tosum

Cyatiogelae cf. suecia

Brakella felix

Baltisphaeridum echinatum

Striatotheca mutua

Peteinosphaeridium velatum

Polygonium cf. gravilis

Goniosphaeridium uncinatum

\subsection{The Section Representing Samples From (7050Wl. - 7071 Wl.) (Thickness 130 meters)}

The section is consisting of red beds of sand with greenish - gray shale and red beds of silt. The samples have been found barren of any type of microfossils, probably represent part of upper Devonian rocks (Perispiki Formation) depending on the regional correlation and its environment of deposition (Seilacher A. 11963, in Buday 1980).

\subsection{The Section Representing Samples (7072 Wl. - 8060Wl). (Thickness 315 meters).}

The section is composed of thin beds of carbonate rocks with intercalation of thin beds of sandstones, siltstone and shale. The samples are found barren of any type of foraminifera. The palynological analyses of the same samples yield many types of pollen and spores. The recorded genera of these microfossils characterize Upper Devonian -Lower Carboniferous rocks (Famennian - Tournaisian age). The section represents the Kaista, Ora and Harur Formations.

The recorded palynomorphs are listed below:

Vallatisporites pusillites

Retispora lepidophytes

Verrucosisporites nitidus

Vallatisporites vellatus

Speleaeotriletes pretiosus

Raistrickia clavata

Vallatisporites verrucosus

Auroraspora macra

Retusotrilletes incohatus

\subsection{The Section Representing Samples from (8067 Wl. -to the top of Paleozoics) (Thickness 824m)}

Chia Zairi Formation, in the present study, the thin sections used by Wetzel R., 1950, are examined, moreover, extra thin sections were prepared from the samples of the exposed section collected by (Wetzel, 1950) and from the cores and cuttings of the subsurface section of the Chia Zairi Formation penetrated in the exploration wells (e. g. jabel kand-No..1, Atshan-1,West-Kifil -1). A 
detailed paleontological study of these of the Chia Zairi Formation was also studied by Youkhanna and Shathaya in an unpublished report (O.E.C1988). A number of the foraminifera and algal genera were identified and recorded in the Chia Zairi rocks, they are considered as index fossils for the Paleozoic rocks. The recorded microfossils in the Chia Zairi Formation fall into two biostratigraphic zones (Youkhanna el.al, 1988). where the lower (older bio-zone) is characterized by the presence of the fusulind genera:

Polyoliexodina - schwagerina and parafusulina, and the upper (younger bio zone) is characterized by the extinction of the mentioned genera and by the presence of the genera Globivalvulina Geinitizina (Lunисummina) with other characterized foraminifera and algal genera that occurs in the Upper Permian rocks. The identified and recorded foraminifera and Algal genera in the Chia Zairi Formation are listed below:

Tuberitina sp.

Lunucammina (Geinitzina) sp.

Pachyphloia sp.

Globoivalvulina bulloides

Nankinella sp.

Sphaerulina sp.

PolyoLiexodina sp.

Schwagerina sp.

Parafusulina sp.

Hemigordius sp.

Algae

Anchicodium sp.

Mizzia velebitana

Epimastopora sp.

Gymnocodium bellerophonite

Permocalculus tenellum

Pseudovermiporella sodalica

Aeolisaccus dunningtoni

Ungdarella uralica

\section{Stratigraphic Correlation of The Paleozoic Rocks}

The exposed Paleozoic rocks in northern Iraq (Chia Zairi,Ora section, Wetzel,1950) are correlated with the Paleozoic rock sections penetrated in the exploration wells e.g. Jabel kand -1, Khlessia 1, Mityaha -1, and wells drilled in the western Iraqi desert, oil well Akkas -1, water wells KH5/1, $\mathrm{KH} 5 / 6$, further to the well Risha -1, drilled near the Iraq - Jordan border (figure -1), the following observations could be noticed starting from the section:

1) The absence of the rocks forming the upper part of the section, Chia Zairi Formation,(Upper Permian ) in the western part of Iraq (well Akkas -1, water wells: $\mathrm{KH} 5 / 1, \mathrm{KH} 5 / 6)$ and further to well Risha -1 in Jordan, while this formation is well developed and attain its maximum thickness towards its outcrop area in northern Iraq.

2) The Upper Carboniferous - Lower Permian rocks (Ga' ara Formation) are penetrated in well, where its exposed in the base of Ga' ara Depression (Rutba High) with thickness of about 727 meters. The formation is missing in northern Iraq and also from wells drilled in 
this region. The upper part of the Ga'ara Formation is penetrated in the deep well West Kifel-1 with thickness of about 72 meters.

3) The Upper Devonian - Lower Carboniferous rocks (Perispi, Chalki, Kaista,Ora and Harur Formations shows almost small difference in thickness is ranging between 445 to 513 meters, starting from north Iraq (the exposed section) to the Western Desert including the penetrated subsurface sections in wells, Khlessia -1, Akkas-1 and water well KH5/1, this part of the section is found missing in the extreme western part of Iraq,well KH5/6 and in the Risha well -3 in Jordan.

4) The Silurian rocks are penetrated in some of the exploration oil wells also in water wells (KH5/1, KH5/6) with rather different thickness. The thickness of the Silurian rocks western Iraq in well Khlessia-1, is 159 meters, while it is 863 meters in well Akkas -1, and it reachs about 279 meters, 690 meters respectively in the water wells KH5/1 and KH5/6. The Silurian section reachs its maximum thickness in wells Risha-1, and Risha 3(2150meters). which is represent by Mudawara and Khisha Formations . The thickness of the Silurian rocks decrease toward the Iraqi, Jordanian border, it is only represented by Mudawara Formation (Lower Silurian) with thickness of about 889 meters in well Risha 1.

In Iraq, the Silurian rocks increases in thickness towards the western desert and decrease towards the north west Iraq in well khlessia-1, while these rocks are missing in the northern Iraq where the Paleozoic rocks are exposed and in wells Jabel kand -1, Mityaha-1, the drilling has not reached this section.

5) The Ordovician rocks (the Khabour Quartzite and shale) are penetrated in the exploration oil wells (Khlessia-1, Akkas-1) with thickness of 1495 and 1912 meters respectively and in both wells the base of the Khabour Formation was not reached. It is penetrated partly and represented by Tremadocian - Ashgillian rocks as have been proved by previous palynological studies.

The Khabour Formation at its type locality, northern- Iraq, with thickness of about 800 meters, was given Landeilian age to the upper part of its section by (R. Wetzel,1950, in Bellen et al,1959). In the present study which is based on palynological study, the geologic age of the Khabour section in its type locality is Tremadocian? Ashgillian - Lianvirnian thus it's extended partly to the lower Ordovician sediments.

6) Based on the above mentioned paragraphs, it seems that some of the formations, which forms the Paleozoic section are partly or totally missing from the stratigraphic succession of the exposed Paleozoic section in northern Iraq (it is not covered by other rocks or sediments) as a result of non- deposition or it has been eroded as this part of Iraq, has been affected by tectonic movements (Caledonian and Hercynian events) which happened during the Paleozoic time.

\section{Conclusion}

Based on the palynological studies of the exposed Paleozoic rocks in northern Iraq and its correlation with the subsurface section in exploration oil wells and water wells, the following conclusions could be derived.

1) The Lower Ordovician section which is represent by samples numbered (7001 W1. - 7048 Wl.) represent Tremadocian -Llanvirnian age for the Khabour Formation. 
2) The Upper Devonian rocks, red in color, starting from sample (7050 Wl.- $7071 \mathrm{Wl}$.) which found barren from any type of microfossils represent the Perispiki Formation .

3) The Upper Devonian -Lower Carboniferous rocks which are represented by samples (7072 W1. -8060 W1.) indicate Famennian- Tournaisian age, represent, Kaista, Ora and Harur Formations.

4) The Upper Permian rocks starting from sample (8067W1. - to the top of the section) represents the Chia Zairi Formation where in this study, are included in two Bio zones:

- The Globivalvulina - Geinitziana zone representing the upper part of the formation.

- Polyoliexodina - Schwagerina - Parafusulina zone representing lower part of the Chia Zairi Formation.

5) Based on the correlation between the exposed Paleozoic rocks and the rocks sections penetrated in the exploration wells drilled in western desert of Iraq show that the following sections are missing in the outcropped section in northern Iraq.

- The upper part of the Khabour Formation.

- The Upper Carboniferous - Lower Permian rocks (Ga 'ara Formation).

- The Silurian rocks (Akkas Formation).

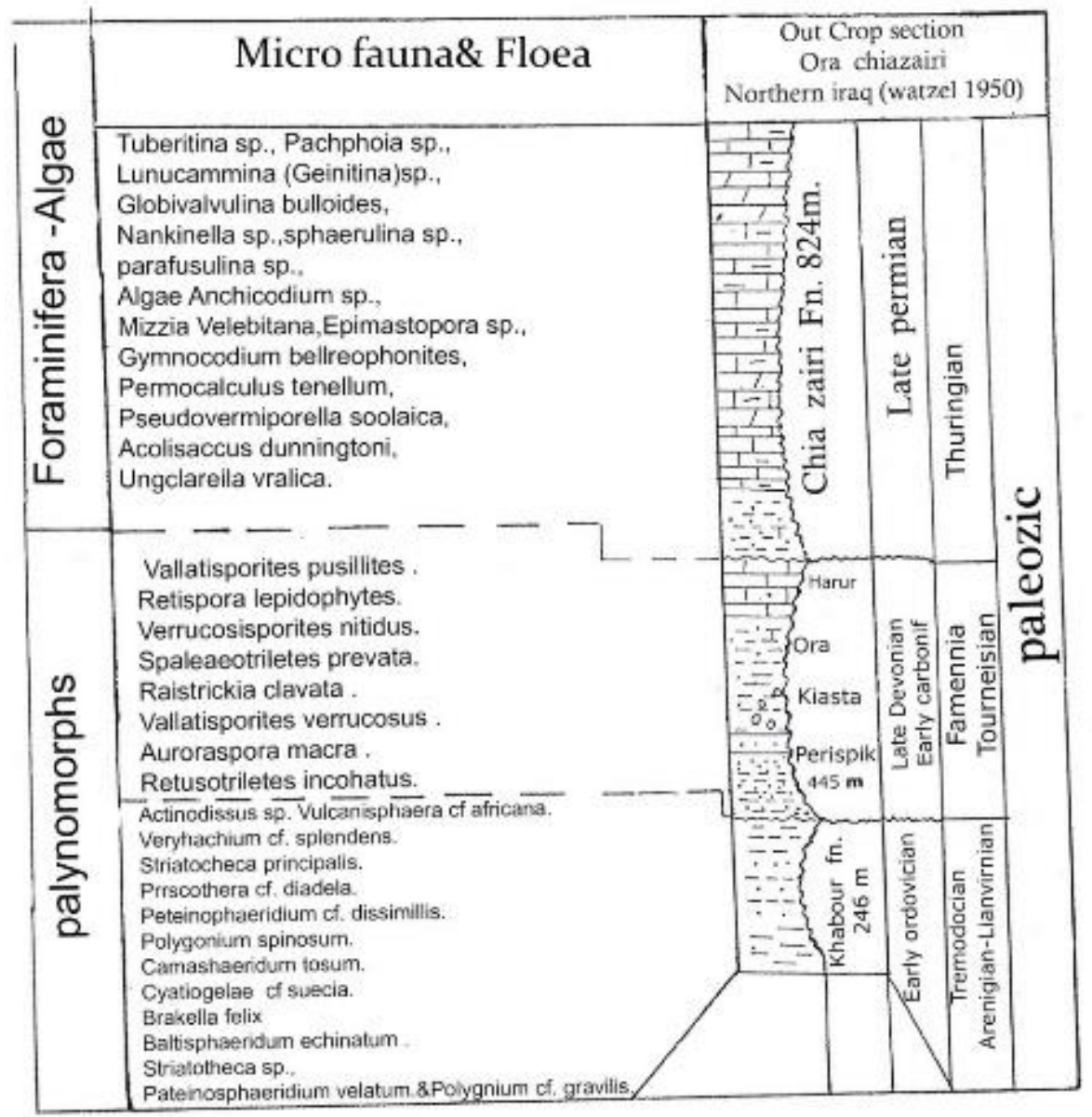

Figure 2: Microfossils (fauna and flora) identified in the section of the Paleozoic formations outcropped in Northern Iraq (Amadia Region)

(Note: stratigraphic section is not to scale) 


\section{References}

[1] AL.Amiri, T. K., AL-Jubori F.H.,AL-Naqshbandy S.F.1991 Lower Silurian palynomorphs from Western Iraqi desert and the Palaeoclimate. Jour. science and nature, university of salahadian Vol.1, No.A, Erbil, Iraq.

[2] AL- Berkadar A.M and Khalaf Al-jubori F.H., 1985: Palynological study of the penetrated section of the water well KH5/1, western desert of Iraq. (Internal Report, OEC, Ministry of Oil, Iraq).

[3] Bellen, R.C.van, Dunnington, H.V., Wetzel R. and Morton D., 1959, Lexique Stratigraphique International Asie, fase, Iraq.

[4] Buday,T. 1980,The regional geology of Iraq Vol.1 stratigraphy and paleogeography D.G, geology surv. Min. investigation, Lib, pub., 1 445pp. 22 text. figures 19 tables .

[5] Falah H.Khalaf and Hanan F. Shatraya 1986: Stratigraphy study of the section from depth 1975 4285 meters of the exploration Oil Well Diwan -1,(in Arabic,internal report ).

[6] Falah H.Khalaf, 1997 Palynological study of the Silurian and Ordovician sediments of the exploration oil Well Khleissia -1. (Internal report)

[7] Falah H.Khalaf 1997 Silurian Organic -Walled Microfossils from Well Risha -1-, Jordan Iraq Geological Journal, and vol 28, No-2 pp.170.184.

[8] Falah H.Khalaf, Akram K.Yonkhanna, Mohammed A.AL-Rubaii and Adnan I. Samurai, 1998. The Akkas Formation, a new name for Paleozoic (Silurian) Lithostratigraphy unit in Iraq. Iraqi Gel .Jour.vol. 30, No.1, (Special issue).

[9] Gaddo, J. and parker D.M.T., 1959: Final well report of Well Khleissia -1, M. P.C. Report, N.O.C. Library, Baghdad.

[10] Final Geological report of well Risha No.3, Jordan, composite logs.

[11] Wetzel R., 1950 Stratigraphy of the Amadiya region, M.P.C. Report. I.N.O.C Library No. TR/RW 12 Baghdad.

*Corresponding author.

E-mail address: falhkh@yahoo.com/falah.aljubori@knu.edu.iq 